\title{
Migrant African Women: Tales of Agency and Belonging
}

\section{Olga Guedes Bailey}

\section{Abstract}

This paper explores issues of belonging and agency among asylum seekers and refugee women of African origin in the UK. It discusses the ways these women engendered resistance in their everyday life to destitution, lack of cultural recognition, and gender inequality thorough the foundation of their own non-governmental organization, African Women's Empowerment Forum, AWEF, a collective 'home' space.

The focus of this story is on migrant women's agency and self-determination for the exercise of choice to be active actors in society. It points to what might be an important phenomenon on how local grassroots movements are challenging the invisibility of asylum-seekers' and refugees' lives and expanding the notion of politics to embrace a wider notion of community politics with solidarity.

AWEF is the embodiment of a social space that resonates the 'in-between' experience of migrant life providing stability to the women members regarding political and community identification.

Key words: migrant women, African migration, agency and belonging, women activism, community networking

\section{Introduction}

Europe is a changing place marked predominantly by neo-liberal market ideologies and conservative politics. This place is characterised by an imagined homogeneous historiography of nationhood, which is compromised by the existence of cultural diversity and otherness (Comaroff, J.L and Comaroff, J. 2009). As the political 
claims of minority groups on redistribution and cultural recognition intensifies, European nation-states have had to come to terms with difference and, in many instances, have granted a variety of measures to counter social and political marginalization (Song 2007). But this does not mean that institutional practices and everyday social relations have changed. For example, while there has been an increase in levels of participation of multiethnic groups in British society, and a more positive approach to difference and diversity in official policy on race, ethnicity and culture, there has also been an increase of less tolerant public discourses and migration policies, especially regarding asylum seekers (Bailey and Harindranath 2006).

In this context, multicultural groups, including asylum seekers and refugee women, are becoming important actors in the struggle for economic redistribution and cultural and political recognition. Fraser (2008) argues that as cultural injustices are entangled and support those of a socio-economic nature, redistributive solutions should include a conception of recognition and vice-versa, that encompasses the complex formation of social identities rather then one that endorses reification. Fraser's concepts are relevant to this article to facilitate an understanding of the struggles for redistribution and recognition of asylum-seekers and refugee women. In the nexus of the injustices of redistribution, and lack of social, cultural and political recognition, it might be possible to position the struggles of asylum seekers and refugee women. Accordingly there is a need to look in different places for new ways in which asylum seekers and refugee women have engendered resistance to destitution (redistribution) and cultural stereotypes (recognition).

This paper explores the case of a group of African women asylum-seekers and refugees in Nottingham ${ }^{1}$, UK and their alternative forms of resistance and belonging through an informal coalition with existing charity organizations and women's groups 
that led to the foundation of their own non-governmental organization, African Women's Empowerment Forum, AWEF. The story here is one of activism situated in everyday life, particularly through organizational and social networking. The women's cause comes to life out of critical self-reflection and awareness of the women asylum seekers and refugees' experiences of exclusion, discrimination, and oppression. This paper aims to discuss the politics of belonging and processes of agency in the space of everyday life among a group of asylum seekers and refugee women of African origin in the $\mathrm{UK}^{2}$. This paper argues that the women's activities is a form of grassroots activism, which empowers women as individuals and as a community ${ }^{3}$ contesting exclusionary systems of representation and participation, by expanding their resistance beyond the boundaries of their homes into the public sphere. It will be divided into four sections. The first briefly contextualise the feminization of migration; the second will attempt to explore the politics of belonging and agency in the everyday life of the migrant African women; the third part will set out the methodological context; the fourth part will tell the story of the creation of AWEF - the organization as a 'home place of belonging' and women's practices of identification and networking.

\section{Feminization of Migration}

Over the past 40 years, migration, forced or otherwise, as a result of the geopolitical relations between the global North and South, has changed the face of Western Europe. The main reaction from governments to the increase of forced migration is to restrict entrance into developed countries and containment methods in the developing world. In the last decade the UK government has created significant new asylum and immigration legislation, which makes granting asylum very difficult.

According to Yuval-Davis, one of the characteristics of the 'age of migration' is 
the feminization of migration. She states that 'the 2004 world survey on the role of women in development states that $49 \%$ of all migrants are women' (2009 p.2). Research on migrant women (Sales 2007; Palmary et al 2010) has showing that, although women are victimized in different situations in the new country, they also work in the junction between oppression and agency to create a better life.

In all cases, women both want and need to work (and many want to study), but are not allowed due to their migration status. This results in problems ranging from economic destitution to poor health, to cultural exclusion and to disenfranchisement. This condition is further exacerbated when one looks at their reasons for migrating, which is mostly politically or economically motivated. The continuing adverse political and economic conditions in parts of Africa have led to substantial migration overseas. In these difficult circumstances they have started a life in a new country. The experience can be alienating and traumatic as it involves a break from their familiar environment and cognitive understanding of the world. Immigration is not only crossing territorial borders but also a cultural, social and psychic boundary and enters into a new relationship in new spaces, the borderlands (Tastsoglou 2006).

The amount of institutions, associations, and organizations that have recently developed around African identity, exacerbated by various territorial and other conflicts, is puzzling. In a global world with economic interdependency and economic and social disparities, among other problems, contemporary migration flux out of Africa is attributed to the failure of nation-states to provide political, social, and economic security to the people (Manger and Munzouli 2006). Similarly the increase of non-governmental organizations caring for ethnic and displaced groups relates to western states' decreasing political will to provide social services for its citizens and non-citizens. Some commentators consider these non-profit organizations core to the 
exercise of agency of civil society in democratic societies (Rifkin 1995, cited in Merrill 2006, p.157). However, critics of this view are concerned with the emphasis on the economic and social role of non-governmental organizations as there is an opportunity to remove part of the responsibility from the state and public agencies as main providers of social services (Craig and Mayo 1995). In addition, nongovernmental organizations can also be a sphere where social inequalities are reproduced (Bryan 2002 cited in Merrill 2006, p. 157).

\section{Migrant African Women: Belonging and Agency in Everyday Life}

The politics of belonging are relevant to an understanding of the trajectory of the African women's exercise of agency. Kannabiran (2006), in her investigation of the cartography of resistance of the Dalit women and their national federation in India, argues that the politics of belonging 'encapsulates within itself the politics of becoming' which occurs 'when a cultural marked constituency, suffering under its current social constitution, strives to reconfigure itself by moving the cultural constellation of identity/difference then in place' (Connolly 1996 quote in Kannabiran 2006, p. 55). In the wider scope of the politics of becoming, African women asylum seekers and refugees perform as actors rather than victims of society, and AWEF becomes the process and space where the politics of becoming/belonging takes place. In this way, belonging refers to both formal and informal experience; not only to the cultural domain - identity and recognition - but also to economic redistribution. Moreover, and relevant to an understanding of the story of the African organization, is a conceptualisation of belonging as the social place constructed by identifications and memberships, and the ways in which social place has resonances with stability of the self, or with feelings of being part of a larger whole with the emotional and social bonds, that are related to such places (Anthias 2006, p. 21). The politics of becoming 
and belonging as discussed here refers to a 'self-conscious movement - a re-invention of the 'we' towards a goal of belonging better somewhere else' (Kannabiram 2006, p. $57)$.

In this scenario one should be able to understand the migrant 'other' in ways that appreciate their modes of dealing with the reality of everyday life (De Certeau 1984), as well as the complex processes of multiple identities and belonging that so often shape the tensions and anxieties carried by those who have experienced migration and displacement. The African women's form of political struggle goes beyond the issue of identity and is based on a solidarity formation which acknowledges the translocational positionalities, 'complexly tied to situation, meaning and the interplay of our social locations' (Anthias 2006, p. 29). In this respect the everyday becomes crucial as a site of contradictions where acts of solidarity, power, alienation and possible resistance are experienced and enacted, as well as a resource for competing reactions and coexistence of both strategies and discourses of belonging and non-belonging (Karner 2007, p.125). In other words, how migrant women position themselves in everyday life to create an organization to negotiate their political identifications and belonging.

The everyday of migrant women is mostly negotiated in the convergence of different cultural influences and constrained by different power structures. Their experiences are lived 'outside' and 'inside' a 'displaced space'. This space is constructed by several axes of differentiation and inequality - nationality, class, gender, ethnicity (Brah 1996) - or, put otherwise, constructed and lived as a 'translocational positionality'. The complex positionality faced by people in the intersection of multiple identity locations, such as that of migrants', should be understood as 'a social process related to practices where positionality is 'the space at 
the intersection of structure (social position/social effects) and agency (social positioning/meaning and practice) (Anthias 2001, p. 635). Positionality in turn becomes an intermediate term between structure and agency, which involves not just locations but also understanding of the ways in which individuals intersubjectively organize, represent or perform identification

The forms of practices of agency performed by these women relate to Knudsen's view on how power is used in intersectionality theory; in Foucaultian sense that power might be linked to both inclusion and exclusion. That is, power is not only about suppression but could also be productive. Thus exclusion would 'involve discourses of opposition and productive power with negotiations about the meaning of gender, race, ethnicity, etc' (2006, p.67). In turn, agency for some of these women is about being 'conscious actors, not passive subjects in the various situations in which they find themselves' (Ralston 2006, p.184). Self-determination in these circumstances entails a counterpoint between 'authentic' self-recognition and social acknowledgement (Taylor 1994). These notions become fundamental to an understanding of the translocational position embedded in the lives and practices of the agency of migrant women.

\section{Methodological Context}

My theoretical approach combines elements of cultural studies with social theory by engaging with the literature on diaspora, refugees and migration, with a particular focus on women migrants, belonging, and agency in the context of everyday life. The purpose of the discussion is to challenge the invisibility of forced migrant women's grassroots struggles while widening the standard conceptualization of politics, - politics based on the public, official actors and workings of governments 
- to focus on 'the community-based struggles of people to gain control over their lives (Feldman and Stall 2007, p. 8).

AWEF's story represents only a small part of the results of a three years' research based on participative action combined with principles of feminist research. According to O'Neill and Harindranath, participative action research is a:

social research methodology that includes the subjects as co-creators of the research. The ethos of PAR is based on inclusion, participation, respecting all local voices, and community driven sustainable outcomes. PAR is a process and a practice directed towards social change with the participants; it is interventionist, action-oriented and interpretive (2006, p. 46).

Moreover, O'Neill argues that:

participatory methodologies offer potential to promote recognition, participation and inclusion in the production of knowledge and public policy. Such methodologies help to challenge dominant discourses and hopefully feed into public policy at local, regional, national and international levels.' (O'Neill 2010, p. 21).

To sum it up, for Fals-Borda (1995, p.1): 'what you finally have in your hands with PAR is a purposeful life-experience and commitment combining academic knowledge with common people's wisdom and know-how'. The feminist research political ethos, which I attempt to follow in my endeavour, is research for women rather than about women (Allen and Baber 1992, p. 4) and the intention is not only to observe and describe women's lives but also to begin 'to draw attention to the political and social struggles of women' (Small 1995, p. 946 ).

I worked with African women asylum seekers in Nottingham while they created and developed their organization. The aim was to trace these women's struggle to 
establish a voice through the creation of their organizational space as well as to support their cause. The premise was that although asylum seekers and refugee women's experiences are mostly marked by subordination and disempowerment, they have the ability and will to reshape and reconstruct their identities, negotiate experiences of belonging and non-belonging and act as conscious agents toward changing their lives. Instead of offering generalising arguments, I chose to focus on a core group of committed women engaged in multiple and interconnected organising efforts. ${ }^{4}$ The qualitative case study allowed me to gather an understanding of the situation of these women, and the changes that have occurred during this time in relation to identity negotiation, political and cultural belonging, and agency. A multiple methodological approach (Castells 1983) was used including interviews, focus group, participant observation and short documentary filmmaking to gain a breadth of understanding. I value participants' collaboration and recognise the importance of their distinctive input with their practical knowledge and experience about the social phenomena investigated.

My social class and race position was not a major issue with the women I engaged with although, at times, I had to explain to few of the newcomers the reasons I was there working with them. Occasionally, I would be referred to as 'the nice white lady' but I did not read too much into it as there was a general feeling of acceptance on both sides and I would like to think that there was a silent mutual agreement to respect our distinct positions while working together. My relationship with some of the women developed few years before I even thought about doing research with them. By the time I proposed the research project, the trust was already generated. During the research process there were occasions when I was asked to help with issues related to health, security, fund raising, and so on, which were important 
moments to confirm my commitment to their cause and to develop further our relations of trust and respect.

The interviews and focus groups involved long conversations (i.e., ten individual interviews and four focus group interviews - average of three to five women per group). A snowball sample approach was used to reach the women; I started with the few women I knew from previous encounters. They then introduced me to other members of the group. The participants of the interviews were women coming from several parts of the African continent, particularly from areas torn by political conflicts. Their ages spread between 18-50 years, with different levels of formal education, work experience, and cause of migration. A bibliographical method directed the interviews, which were participant-led in terms of the direction of the conversations and willingness to reveal their stories. The questions were organized following Feldman and Stall's methodology (2007). They thus provided an overview of the woman's family, education, work, migration history, description of their life in the new country, an examination of involvement with the group (in terms of activism or voluntary work), including aspiration and motivations for community work, understanding of the problems faced by asylum-seekers and refugees and expectations for the future. In the focus groups, we explored issues related to asylum/refugee policy and its effects on their lives, notions of home and belonging, identity, prejudice and racism, destitution, 'banal' forms of resistance in their everyday life, and aspirations to change the future. As part of the participant observation process, I attended meetings and events on a regular basis, such as skill development workshops and social gatherings.

The analysis of the material was constructed reflecting a thematic nexus of migration-women-agency-belonging. The explanatory framework used grounded 
theory developed during data collection through observation (Charmiz 2006; Morse et al. 2008). An initial set of categories of analysis for interviews were organized according to Brah's (1996) four modalities of difference: experience, social relations, subjectivity and identity. Feldman and Stall summarise these modalities as: 'experience as related to symbolic constructions in struggles over material conditions and meanings; social relations as contexts for systematic relations mediated by institutional discourses and practices; subjectivity as the site of self-in-the-world sense making; and identity as coherent, and stable' (Feldman and Stall 2007, p. 104). In my analysis, among other elements, these modalities of difference were helpful in identifying how women's perception and experiences of being 'different' might have influenced their awareness and will to change their situation of destitution and lack of recognition. By and large, the research process was very dynamic as simultaneously I collected, coded, and analysed data to inform the next phase of the investigation.

\section{Telling a story: African Women Empowering Forum in the making ${ }^{5}$}

The tension between African migration caused by political problems and the increase in non-governmental organizations due to western nation-state failures, as mentioned earlier, is reflected in AWEF. This organization is positioned at the intersection of an increasingly multicultural Europe, which is constituted by new forms of alliance and interethnic politics. It could be suggested that AWEF is an example of a 'postcolonial grassroots politics' (Merrill 2006, p. 156) that represents numerous differences - ethnicity, class, nationalities, gender, and ideologies. The process of creating the organization, which would typify a community space of advocacy, took a while. A small group of asylum-seeker and refugee women discussed their situation and possible solutions to improve their material conditions in 
meetings among themselves and with other supporting organizations. In 2006 they produced a 'constitution' according to which they, as African women, could represent themselves. As put by one of the interviewees:

With a group of fellow women we formed the African Women's Empowerment Forum because we experienced first hand the issues that asylum seekers have to deal with - the prejudices, racial discrimination and oppression in society particularly in issues that affect women. I would meet with other women like me at the Victoria shopping centre because we had nowhere else to go. Many times we cried together when we talked about our situations and wonder what we could do. We started to help each other... (interviewee A).

AWEF's headquarters is situated in the city centre of Nottingham, next to the railway station, in a three-floor building provided by the local authorities. AWEF pays rent to share the premises with several non-governmental organizations. The daily work of running AWEF, from cleaning to cooking to coordinating events, to public relations, is supported by women's voluntary work. I also worked as a volunteer, and after the research ended was elected vice-chair of the AWEF Trustee Board.

The aims of the Forum are to 'advocate for women's rights and empower them through education and training'. The organization was created to 'stir them to speak out and challenge inequalities in society; to advocate for women on gender issues, equality of access and non discrimination, based on race, gender, age or immigration status' to have an input on policies locally and nationally; and to promote a sense of belonging as well as value being responsible citizens in a foreign land' (AWEF 2006, 
p.3). The organization is funded by different sources including the Nottinghamshire Foundation, the Community Champions and local authorities.

AWEF is proactive in engaging women on cultural issues and general integration into local and British society, in assisting children of African origin to maintain their identity and confidence to become responsible citizens. Their association with the voluntary sector is important to the development of their wider network of support with which they form long or temporary alliances. Partners range from the Nottinghamshire Black Partnership, the Red Cross, Rainbow Project, and City of sanctuary of Nottingham, to local universities, among others.

AWEF is also a space for recreational, social, religious and cultural celebration of difference, as well as of commonalities within a British cultural context. Different occasions bring together Africans and people from different ethnicity-nationalitygender and give the women a sense of cultural belonging, solidarity (without denying the conflicts) and an awareness of their positionality in the new society:

We have functions together, cook Zimbabwe food, play African music ${ }^{6}$ - just socialising. It makes me feel at home, feel like I'm part of a family. It gives me a sense of belonging and in that process we also feel that Nottingham is now our home... we share common things of Africa but we belong to different cultures and this generates conflict. It is a challenge to us. (interviewee B)

Recently the organization conducted a survey among members in order to ensure that their programme is focused on their needs and that it impacts positively on the community it serves. The findings show that $95 \%$ are asylum seekers without legal status; $3 \%$ have refugee status; and $2 \%$ are migrant workers on work permits. The majority (76\%) are between 31 and 60 years old. $12 \%$ are between 21 and 30 , and $8 \%$ are younger than 20 years old. The women come from Somalia, Democratic Republic 
of Congo, Sudan, Zimbabwe, and Malawi. $75 \%$ of the women have children, mostly teenagers. $25 \%$ of children are under 5 years and 30\% are aged between 6 and 12 years old. About $55 \%$ out of 242 members have had to leave children at home. Most live in deprived areas of the city of Nottingham. The women in the survey are educated to high school level with $60 \%$ having diplomas for specific professions such teachers; $35 \%$ have degrees and $5 \%$ have postgraduate qualifications. Most of the women are unemployed as they do not have permission to work but many are working as volunteers for AWEF. Only 5\% are in paid work. They have been in the UK on an average of 5-10 years. $85 \%$ of the women suffer health problems including stress, blood pressure, and respiratory problems (AWEF 2008).

\section{AWEF as 'Home Place' of Belonging}

The starting point is perhaps to think of their organization (both as a process and as an institutional space) as a 'home place' in the expression of both power and resistance for African women. This concept of 'home place' as a space of resistance was developed by hooks (1990). Her proposition was that historically, AfricanAmericans' struggles to make and sustain a home place and community offered more than providing for the daily needs; it also had a 'radical political dimension... despite the reality of domination, one's home place was the one site where one could freely confront the issues of humanization, where one could resist'( $(p .42)$. This role of space appropriation in the expression of daily resistance is grounded in the work of Foucault's proposition that places are not only sites of dominance; they are also sites of resistance (1979). Places and spaces reflect both 'the desires of some groups of people to reproduce the social order in which they are dominant, as well as the attempts by those without such power to resist and survive in a way that is meaningful in their lives' (Wolf 1990 p.3 cited in Feldman and Stall 2007, p. 12). 
The association of these displaced women became their 'home place' where they interact with other women displaying a communal identity, whether it is religious, national, regional (African) or ethnic. Consequently, they share their cultural and political vision, concerns, and seek support for their social problems. For them, a physical place to call home (organization) is rather crucial to develop bonds with both the social and the physical environment of their new home. In this case, the importance of the home place (as a place of belonging and becoming) exceeds the necessity of functional and material support for shelter and security as attested by interviewee A:

We became stronger as a group and they gave me strength to keep going. The organization is our home, is our shelter, our 'mother' as we cannot leave down our things to the authorities to listen [resolve] to us.

Moreover, having a personal political space to voice and share their stories was facilitated in the process of participatory research, which allowed all those involved to reflect on the different layers of the process taken place - action for changes. As O'Neill emphasises 'engaging and connecting with feelings, intellect and politics that mediate the tensions between emotion and materiality can help us to understand better the "micrology" of migrants' live' in the wider socio political context of migration. (O'Neill 2010, p. 170) Given the connections between what Fraser (2008) refers to as redistributive and recognitive injustice and Knudsen's argument on the power of exclusion to produce agency, it is understandable that, in order to confront the oppressive reality they face, AWEF women have extended their resistance beyond the local and into the public sphere by actively engaging with policy-makers, nongovernmental organizations, local and national governments to create awareness of the problems faced by asylum seekers: 
We have suffered discrimination and even verbal abuse in the streets. Apparently

Nottingham has a high level record of discrimination but I must say that we managed to influence a number of agencies to support us (interviewee C).

The daily running of AWEF is expressed by many of the women in a family idiom - home place and 'mother'- cultivating and mobilizing the social bonds to develop the organization. However, women's partnership around gender and ethnic experiences of commonality is also marked by diversity. Diversity generates at times, tensions due to their conflicting ideologies, histories, and social positions inflecting on their basic similarities. These women come from diverse political, generational, cultural, religious and class backgrounds, thus differences also reflect pre-existing and continuing differences associated with pre-existing socio-geographical dynamics. Mostly, it seems they have learned to negotiate their differences, through acknowledging tensions. The women's commitment to the wider cause, as well as their strong emotional ties, supports their participation in shared activities beyond difference and occasional tensions.

\section{Practices of identification and networking}

For these African women the process of migration to the UK has led to a fundamental negotiation of identities, resulting from the located politics of becoming that then shapes the politics of belonging and alters the idea of community symbolised by the creation of AWEF. The awareness of multiple identities associated with different forms of belonging has reshaped many of these women's identities. The complexities of these processes are hard to pin down and can only be suggested. For many women, migration meant a loss of autonomy and freedom, even though many were running away from situations of political upheaval in which their lives were 
endangered. For others, migration opened up possibilities of self-improvement in spite of the difficulties faced in the new country:

I was a successful lawyer at home but here I couldn't work and was destitute, which was very depressing. When I got my refugee status I decided to study and got a MA degree in law. Now I am working at a law firm in an apprenticeship before I can work as a full lawyer. (interviewee C).

Political empowerment can be perceived in the organization's activities where there is an underlying urgency for the women to reinvent and redefine themselves in order to place a legitimate group identity before society. Thus, the incorporation of a cultural identity is implicated in the genesis of a newly institutionalised 'African women asylum seekers' political identity. In addition, networking with other organizations has helped many to develop civic and political skills (political in a wider sense), build interpersonal trust, foster feelings of belonging, and reconstruction of their identities. They have also developed a healthy relationship with the local print and broadcast media who cover most of their events in a positive tone with in-depth stories showing their resilience and hard work ${ }^{7}$. At the organizational level, networking reinforces AWEF as an active social actor in the migration sector as well as a build up for the interactive network of multi-layered communication systems of communities. This is what Castles (1997) calls 'women of communities' to include the host of feminist organizations, support networks, clinics, refuges and cultural associations that support women in need.

Only in the last two years have AWEF women started to use information and communication technologies (ICT). Their web page appeared in 2010, with the slogan 'educate a woman and empower a nation' (AWEF, 2010) resonating perhaps a traditional utilitarian vision of women in relation to the (new) nation or perhaps just a 
marketing strategy where a sense of nationalism is hinted but not explicit towards any particular nation. The website's aim is to develop a local, national and transnational conversation with other 'sister' organizations to articulate a polyvocal dissent based on common concerns and successful stories to a wider audience. The ability to gain a voice in the online territory, as a discursive space, is rather valued by the women as it reinforces their empowerment as an ethnic group (Mallapragada 2006).

AWEF has come to advocate a modern identity that involves both the management of mainstream knowledge and skill systems' for its members and the creation of an economic venture based on the members' national, ethnic, gender and migration legal status. This modern identity can be observed at three levels. Firstly, in certain respect, AWEF is a formal organization with a set of rational, instrumental concerns, relating to mobilising resources and achieving specific aims that position them in the political sphere. Secondly, it also plays an important social role in the everyday life of African women; the women promulgate ethical behaviour, and campaign against racism and discrimination, which are entrenched in daily life activities blurring their public and private lives, and making connections with the local, the national and the global. Thirdly, the organization is a non-profit business speaking a different idiom, which is infusing everyday talk, especially at moments when women strive to craft a means of survival by presenting what is the 'asylum seeker brand' with what is their 'African life-style' in terms recognizable to others (Comaroff and Comaroff, 2009). The language or public discourse of the organization is also positioned in terms of business management and what they can offer to the community, knowing over time, that they will be subjected to the attentions and measurements of the local authority community workers as well as the wider society. As interviewee A points out: 
We need to have a strong business approach to address the authorities. To talk about our 'stories' is not enough anymore. We have to present what we are doing (organization) with records, plans etc. Refuge is now an industry.

For the AWEF women, asylum seeker and refugee identity is a recent social construct that matters only at a certain level, as what counts is establishing a recognized presence as a confident, future-oriented ethno-organization based on solidarity. In fact, for many of its members, AWEF has become a term of selfreference. It describes an imagined cultural community that is itself transnational, bringing together many of the African countries into Britain. The project initiated by the women is reaching towards a sense of collective political and cultural entity. In that way the organization is able to achieve its mission to help maintain an identity based on an appeal to difference, while closing the gap between them and the wider community by preserving the emotional, cultural, political and communitarian ethos of their enterprise.

Following Comaroff and Comaroff's (2009) analysis of African ethnicities, it can be suggested that in the process of its creation and consolidation, AWEF has somehow naturalized the trope of identity, which the women' struggle for political belonging and cultural recognition so strongly highlights. Thus African women asylum seekers and refugees once dispersed have become an 'African women's empowerment forum' replete with a sense of ethno-national-engendered identity, its own agency to change lives, and its own home place (organization) to make it a reality. Combining a language of homeland and ethnicity, with migration status and the business ethos in pursuit of an African space in the UK, their claims on particularistic, and universalistic rights requires both the incorporation of identity and a cultural essence to realize, recognize, and accomplish itself. It is a 'living 
tautology': without the first, it would have no independent materiality; without the second, it would be indistinguishable from any other species of [non-governmental] enterprise (Comaroff and Comaroff 2009, p.116)

\section{Conclusions}

This article has attempted to explore the practices of belonging and agency of a group of African asylum seeker women in Nottingham through the work of the African Women's Empowerment Forum. In looking at this particular political formation, what hopefully becomes clear is that AWEF is a new and distinct space in which a group of African women have engendered agency to secure social justice and recognition, in a process that allows for 'the politics of becoming to shape the politics of belonging and transform the idea of community itself' (Kannabiran 2006, p. 68). This process of agency also allows for a convergence between everyday and political society. In the thematic nexus of women-migration-belonging-agency it is possible to suggest that these women have constructed an organization that has changed the lives of many women ${ }^{8}$, a work recognised in 2009 and in 2011 by the national government, and in the process, has had an impact upon traditionally received notions of women asylum seekers.

The story of AWEF is not just another story. Instead it points to what might be an important phenomenon on how local grassroots movements are challenging the invisibility of asylum-seekers' and refugees' lives and expanding the notion of politics to embrace a wider notion of community politics with solidarity.

The organization has developed well because of the members' ability to negotiate and renegotiate difference, and move between different spheres and interact with different social actors in order to build their own space, which they regard as a home. 
Migrant life is constructed in between spaces where belonging involves the emotional, the imaginary, and the rational, all of which reflect into the cultural and political life. AWEF is the embodiment of a social space that resonates these elements by providing a context of stability to the women members regarding political and community identification.

There are theoretical and practical difficulties in analysing an emergent and complex organization that results from an interethnic alliance because of the different positionality of its members 9 . In fact AWEF's experience is not without criticism or disagreement. However it has become a good example of the exercise of a grassroots activism despite its continual differences, a form of 'integration politics from below' (Pero 2008) that challenges mainstream stereotyped ideas about refugees and asylum seeker women as victims by showing a group of self empowered women. AWEF women have developed a space formed in a double movement between 'counter hegemonic' everyday resistance and recognition of neo-liberal and capitalist forces that co-exist in society. In this context, I would argued that, in the current climate of fear of global threats and scepticism with the status quo, it is rather refreshing to see an authentic attempt to empower underprivileged women through a gender network experience of affiliation and engagement 


\section{REFERENCES}

ALLEN, KATHERINE R. and BABER, KRISTINE M. 1992 Ethical and epistemological tension in applying a postmodern perspective to feminist research, Pshychology of Women Quartely, Vol. 16, pp. 1-15 9 ( used online version 2006) AMIT, VERED AND RAPPORT, NIGEL 2002 The Trouble with Community: Anthropological Reflections on Movement, Identity and Collectivity. London: Pluto Press

ANTHIAS, FLOYA 2001 'New hybridities, old Concepts: the limits of culture', Ethnic and Racial Studies, vol. 24, no. 4, pp. 619-641

ANTHIAS, FLOYA 2006 'Belonging in a globalising and unequal world: rethinking translocations', in Nira Yuval-Davis, Kalpana Kannabiran and Ulrike Vieten (eds), The Situated Politics of Belonging, London: Sage, pp. 16-31

AWEF - AFRICAN WOMEN EMPOWERMENT FORUM 2008 Report on Profile of its Members, p. 2

AWEF - AFRICAN WOMEN EMPOWERMENT FORUM 2010

http://www.awef.org.uk/cms/ (accessed March 2010)

BAILEY, OLGA . G. and HARINDRANATH, RAMASWAMI 2006 'Ethnic Minorities and the Politics of Communication in Multicultural Britain and Australia', International Journal of media and Cultural Politics, vol. 2, no.3, pp. 299-316.

BRAH, AVTAR 1990 Cartographies of Diaspora: Contesting Identities, London: Routledge

BRYAN, RAYMOND 2002 'Non-governmental organizations and governmentality: consuming biodiversity and indigenous people in the Philippines', Political Studies, vol. 50, pp. $268-92$ 
CASTELLS, MANUEL 1983 The City and the Grass Roots, Berkeley: University of California Press

COMAROFF, JOHN L. and COMAROFF, JEAN 2009 Ethnicity, Inc. Chicago: The University of Chicago Press

CONNOLLY, WILLIAM, E. 1996 'Suffering, justice, and the politics of becoming', Culture, Medicine, and Psychiatry, vol.20, pp.251-77

CRAIG, GARY AND MAYO, MARJORIE (eds) 1995 Community Empowerment, Atlantic Highlands, NJ: Zed Books.

FALS-BORDA, ORLANDO 1995 'Research for social justice: some North-South convergences' (http://comm-org.wisc.edu/si/falsborda.htm)

FELDMAN, ROBERTA. M. and STALL, SUSAN 2007 The Dignity of Resistance; Women Residents' Activism in Chicago Public Housing, Cambridge University Press FOUCAULT, MICHAEL 1979 Discipline and Punish: The birth of the prison. New York: Vintage

FRASER, NANCY 2008 'From redistribution to recognition? dilemmas of justice in a 'postsocialist' age, in Kevin Oslom (ed.), Adding Insult to Injury; Nancy Fraser Debates Her Critics, London: Verso, pp. 9-41

KARNER, CHRISTIAN 2007 Ethnicity and Everyday Life, London: Routledge. HOOKS, BELL 1990 Yearning: Race, Gender, and Cultural Politics, Boston, US: South End Books

KNUDSEN, SUSANNE V. 2006, 'Intersectionality - A Theoretical Inspiration in the Analysis of Minority Cultures and Identities in Textbooks', in Eric Bruillard, Mike Horsley, Susanne V. Knudsen and Bente Aamotsbakken (eds) Caught in the Web or lost in the Textbook. Paris: IUFM de Caen, pp.61-76 
MALLAPRAGADA, MADHAVI 2006 'Home, Homeland, Homepage: Belonging and the Indian-American Web', New Media \& Society, vol. 8, pp. 207- 27

MANGER, LEIF and ASSAL, MUNZOULI 2006 (eds), Diasporas Within and

Without African: Dynamism, Heterogeneity and Variation, Uppsala: Nordiska Afrikaininstitute

MERRILL, HEATHER 2006 An Alliance of Women: Immigration and the politics of race, Minneapolis: University of Minnesota Press

O'NEILL, MAGGIE 2010 Asylum, Migration and Community, Bristol, UK: The Policy Press

O'NEILL, MAGGIE AND HARINDRANATH, RAMASWAMI 2006 'Theorising narratives of exile and belonging: the importance of biography and ethno-mimesis in “understanding” asylum', Qualitative Sociology Review, vol. 2, pp. 39-53 PALMARY INGRID, BURMAN, ERICA, CHANTLER, KHATIDJA, and KIGUWA, PEACE (eds) 2010 Gender and Migration; Feminist Intervention. London: Zed Books.

PERO, DAVIDE 2008 'Integration From Below. Migrants' Practices of Citizenship and the Debate on Diversity in Britain', Working Paper no.2, University of Nottingham, $\quad$ http://www.nottingham.ac.uk/icmic/documents/pero-icmic-wp-08$\underline{\text { 02.pdf }}$ (retrieved January 2010)

RALSTON, HELEN 2006 'Citizenship, identity, agency and resistance among Canadian and Australian women of South Asia', in Evangelia Tastsoglou and Dobrowolsky (eds), Women, Migration and Citizenship; Making Local, National and Transnational Connections, Aldershot, UK: Ashgate Press, pp. 183-200 RIFKIN, JAQUELINE 1995 The End of the World: The Decline of the Global Labor Force and the Dawn of the Post-market Era. New York: G.P Putnam's Sons. 
SALES, ROSEMARY 2007 Understanding Immigration and Refugee Policy: Contradictions and Continuities. Bristol: The Policy Press.

SMALL, A. STEPHEN 1995 'Action-oriented research: models and methods', Journal of Marriage and the Family, vol.57, no 4, 941-955 (http://academic.son.wisc.edu/courses/n701/week/small models.pdf accessed 10 January 2011)

SONG, SARAH 2007 Justice, Gender, and the Politics of Multiculturalism, Cambridge: Cambridge University Press

TASTSOGLOU, EVANGELIA 2006 'gender, migration and citizenship: immigrant women and the politics of belonging in the Canadian Maritimes', in Evangelia Tastsoglou and Dobrowolsky (eds), Women, Migration and Citizenship; Making Local, National and Transnational Connections, Aldershot, UK: Ashgate Press, pp. $200-230$

TAYLOR, CHARLES 1994 'the politics of recognition', in Amy Gutmann (ed.) Multiculturalism: Examining the Politics of Recognition. Princeton, NJ: Princeton University Press, PP. 12-34

YUVAL-DAVIS, NIRA (2009) 'Gendered globalisation and social change'. In Focus. June 22. http://barha.asiaportal.info/node/974 (accessed March 2010) WOLF, MICHELLE. (1990, July) 'Whose Culture? Whose Space? Whose History? Learning from Lesbians bars'. Key note address at the $11^{\text {th }}$ Conference of the International Association for the study of people and their surroundings (IAPS) Ankara, Turkey. 
OLGA GUEDES BAILEY is Senior Lecturer in the School of Arts and Science, Institute of Cultural

Analysis at Nottingham Trent University.

ADDRESS: School of Arts and Sciences/Institute of Cultural Analysis, Nottingham Trent

University, Clifton Lane, Nottingham, NG11 5ND, UK. Email: olga.bailey@ntu.ac.uk

\begin{abstract}
${ }^{1}$ The discussion presented is not claiming that the story told here reflects the experience of such women generally in the UK.

2 'Migrant women' refers to a group of African women asylum seekers and refugees living in Nottingham, UK. 'African women' refers to a heterogeneous group of women of African origins with distinct histories of migration as well as different political, economic, cultural and social backgrounds

${ }^{3}$ Community is used as 'rhetorically, communities may represent themselves to themselves, as well as to others, as homogeneous and monolithic, as a priori, but this is an idiom only, a gesture in the direction of solidarity, boundedness and continuity. The reality is of heterogeneity, process and change; of cultural communities as diverse symbolizations which exist by virtue of individuals' ongoing interpretations and interactions' (Amit and Rapport 2002, pp. 7-8)
\end{abstract}

${ }^{4}$ This article presents an overview of some of the core issues investigated in the wider project. The three women's voices presented are of the key women at AWEF central organization who were involved in the process from the beginning and are still involved in the development of the organization. In my view they are representative of the different aspirations, age, class and ethnic background of the wider group of women members of AWEF.

${ }^{5}$ The following section presents the story of the creation of AWEF articulating a narrative drawn from the interviews reflecting the points of agency, belonging, recognition and redistribution.

${ }^{6}$ The country refers to a national identity while African refers to an ethnic identity. As a political strategy the women use the combination of the ethnic and gender markers of identity to promote their organization.

${ }^{7}$ See for example article on AWEF on refugees week, in 2010

http://www.awef.org.uk/index.php?id=press\&event=This\%20is\%20Nottingham\%20article\%20publish ed $\% 20$ by $\% 20$ the $\% 20$ Nottingham\%20Post $\% 20$ on $\% 2017$ th\%20June $\% 202010 \% 20$ by $\% 20$ Erik\%20Peter sen

${ }^{8}$ Since this article was written several women have obtained refugee status and moved on to pursue a carrier and obtain academic and professional qualifications in order to integrate in British society.

${ }^{9}$ It is not the aim of this paper to raise these theoretical problems. 